\title{
ANALISIS PENGELOLAAN ARSIP DINAMIS DAN STATIS DI MTs NEGERI 2 PRINGSEWU LAMPUNG
}

\author{
$\operatorname{Ngadiyah}^{(1)}$, Arohman $^{(2)}$ \\ Program Studi Manajemen, Fakultas Ekonomi dan Bisnis Universitas Muhammadiyah Pringsewu \\ Jl. KH. Ahmad Dahlan no.112 Pringsewu Lampung 35373 \\ Email : jazulingadiyah@gmail.com
}

\begin{abstract}
Abstrak
Setiap kegiatan keorganisasian baik organisasi pemerintah ataupun swasta seperti organisasi pada lembaga pendidikan membutuhkan informasi sebagai penunjang kegiatan administrasi dan pelaksanaan menejemen suatu organisasi. Salah satu sumber informasi sebagai penunjang kegiatan tersebut adalah arsip. Arsip adalah setiap catatan tertulis baik dalam bentuk gambar atau pun bagan yang memuat keterangan-keterangan sesuatu subyek (pokok persoalan) atau pun peristiwa-peristiwa yang dibuat oleh orang untuk membantu daya ingat orang itu. Dari segi fungsinya arsip itu terbagi menjadi dua yaitu arsip dinamis dan arsip statis, Dengan melihat pentingnya arsip bagi kehidupan organisasi, sehingga arsip tersebut perlu dikelola dengan baik.
\end{abstract}

Masalah dalam penelitian ini adalah kompetensi yang dimilki pegawai tata usaha MTs $\mathrm{N} 2$ Pringsewu tidak sesuai dengan tugas pokok dan fungsi dari masing-masing pegawai, namun hasil pekerjaan yang berkaitan dengan pengelolaan arsip disekolah tersebut baik dan optimal. Tujuan dalam penelitian ini adalah untuk mendeskripsikan dan menganalisis pengelolaan arsip di MTs N 2 Pringsewu serta melihat kelebihan dan kekuranganya.

Analisis data menggunakan teori miles and Hibermen yang meliputi reduksi data, penyajian data dan penarikan kesimpulan. Berdasarkan hasil analisis data diperoleh data a) Pengelolaan arsip dinamis di MTs N 2 Pringsewu yang sebagai berikut: pertama, Penciptaan Arsip yang meliputi Penciptaan arsip pada Surat Keluar dan Surat Masuk. Pengunaan Arsip Dinamis di MTs N 2 Pringsewu, kedua, Penggunaan arsip meliputi peminjaman dan penemuan kembali arsip. Ketiga, Pemeliharaan Arsip yang meliputi penyimpanan dan perawatan, keempat, Penyusutan Arsip Dinamis, Belum adanya pelaksanaan penyusutan arsip dalam pengelolaan arsip yang dilakukan di Bagian Tata Usaha MTs N 2 Pringsewu, hanya terdapat proses pemilihan arsip dinamis yang masih digunakan (berumur 1-3 tahun) tetap disimpan dalam lemari, sedangkan arsip yang sudah tidak digunakan lagi atau berumur lebih dari 3 tahun dipindahkan ke dalam gudang. Begitu pula dengan arsip dinamis yang berupa SPJ gaji. b) Pengelolaan Arsip Statis di MTs N 2 Pringsewu sebagai berikut: pertama, Akuisis Arsip, Akuisisi arsip yang dilakukan di MTs N 2 Pringsewu masih sebatas penyerahan dari pencipta kepada lembaga kersipan, dalam hal ini bagian Tata Usaha di Mts N 2 Pringsewu, kedua, Pengolahan Arsip Statis yang meliputi pendeskripsian arsip, penyatuan sesuai dengan golongan setelah itu pengkodean. Ketiga, Preservasi arsip (Pemeliharaan) dilakukan dengan cara pembersihan fisik arsip, meberikan kapur barus di dalam lemari tempat penyimpanan arsip. Selain itu juga rutin melakukan pengecakan lemari atau tempat penyimpanan arsip, adapun untuk perawatan sama dengan perawatan arsip dinamis, yaitu dengan memberikan kapur barus dan membersihkan arsip-arsip menggunakan kemoceng atau lap yang dilakukan secara rutin. Ke empat, Akses arsip statis, Sistem yang digunakan untuk memumdahkan dalam menemukan kembali arsip yang dibutuhkan dilakukan dengan membuat pengkodean pada arsip dan arsip diletakan di map ordner.

Kata Kunci: Pengelolaan Arsip Dinamis dan Statis.

BAB I PENDAHULUAN

A. Latar Belakang
Pada dasarnya setiap kegiatan keorganisasian baik organisasi pemerintah ataupun swasta seperti organisasi pada lembaga 
pendidikan membutuhkan informasi sebagai penunjang kegiatan administrasi dan pelaksanaan menejemen suatu organisasi. Salah satu sumber informasi sebagai penunjang kegiatan tersebut adalah arsip.

Madrasah Tsanawiyah Negeri 2 (MTs N 2) Pringsewu adalah salah satu lembaga pendidikan dibawah naungan Kementerian Agama setingkat Sekolah Menengah Pertama (SMP) yang ada di Kabupaten Pringsewu tepatnya di Pekon Sukamulya. Madrasah ini menjadi salah satu madrasah dengan kwalitas yang unggul, ini dibuktikan dengan Surat keputusan yang dikeluaran oleh Badan Akreditasi Sekolah/Madrasah dengan nomor 580/BAN-SM/SK/2019 pada tanggal 02 juli 2019 bahwa Sekolah ini mendapat Akreditas A. Nilai Akreditasi tersebut diperoleh tidak hanya dari sisi pelaksanaan organisasi baik, kelengkapan sarana dan prsarana tetapi juga karena pengelolaan arsip yang baik. Sebagaimana yang diungkapkan oleh Ibu Waljiemah, M.Pd selaku kepala MTs N 2 Pringsewu, "Madrasah ini menjadi salah satu lembaga yang mendapat nilai Akreditasi A, ketercapaian ini bukan semata karena pelaksanaan kegiatan pembelajaran yang baik, sarana dan prasaran yang lengkap tetapi juga kinerja yang baik yang ditunjukan oleh semua unit termasuk unit Tata Usaha (TU) yang sudah melakukan tugasnya dengan baik di bidang kearsipan".

Selain itu madarasah ini memiliki bagian Tata Usaha yang dilihat dari latar belakang pendidikan tidak sesuai dengan bidang pekerjaan, bahwasanya kompetensi yang dimilki tidak sesuai dengan tugas pokok dan fungsi dari masing-masing pegawai, namun hasil pekerjaan dari masing-masing pegawai yang berkaitan dengan pengelolaan arsip disekolah tersebut baik dan optimal. Ini dibuktikan penyusunan berkas-berkas penting yang rapih dan teratur sesuai dengan jenis berkasnya, adanya lebel di setiap berkas yang tersimpan sehingga dapat dengan mudah untuk mencari dan menemukan berkas yang dibutuhkan dan juga adanya catatan serta data peminjam berkas, sehingga berkasberkas yang dipinjam mudah dilacak dan dicari. Dengan demikian pegawai tata usaha tidak mudah kehilangan berkas. Oleh karena itu penulis tertarik untuk menganalisa pengelolaan arsip baik arsip dinamis maupun statis di sekolah tersebut.

\section{B. Rumusan Masalah}

Berdasarkan Latar Belakang masalah di atas, penulis merumuskan masalah dalam penelitian ini sebagai berikut :

1. Bagaimana pengelolaan arsip dinamis dan statis di MTs N 2 Pringsewu?

2. Apa kelebihan dan kekurangan dari pengelolaan arsip dinamis dan statis di MTs N 2 Pringsewu?

\section{Tujuan Penelitian}

Sesuai dengan latar belakang dan rumusan masalah yang tertulis, tujuan dari penelitian ini adalah:

1. Ingin mengetahui pengelolaan arsip dinamis dan statis di MTs N 2 Pringsewu.

2. Ingin mengetahui kelebihan dan kekurangan daari pengelolaan arsip dinamis dan statis di MTs N 2 Pringsewu.

\section{BAB II TINJAUAN TEORITIS}

\section{A. Landasan Teori}

1. Konsep Kearsipan

Menurut Undang-undang Nomor 43 Tahun 2009 dalam Bab I Ketentuan Umum Pasal 1 tentang kearsipan, yang dimaksud dengan arsip adalah "Rekaman kegiatan atau peristiwa dalam berbagai bentuk dan media sesuai dengan perkembangan teknologi informasi dan komunikasi yang dibuat dan diterima oleh lembaga negara, pemerintah daerah, lembaga pendidikan, perusahaan, organisasi Politik, organisasi kemasyarakatan, dan perseorangan dalam pelaksanaan kehidupan bermasyarakat, berbangsa, dan bernegara".

a) Fungsi dan peran arsip

Arsip mempunyai fungsi dan peran tersendiri di dalam sebuah organisasi. Adapun fungsi dari arsip menurut (Muhidin dan Winata, 2016:3) beberapa fungsi arsip sebagai sumber informasi yang dapat dimanfaatkan untuk kepentingan yaitu:

1) Mendukung proses pengambilan keputusan. Dalam proses pengambilan keputusan, pimpinan dalam tingkat manajerial manapun pasti membutuhkan informasi. Ketersediaan informasi yang 
cukup, baik dari segi kualitas maupun kuantitas, dapat mendukung tercapainya tujuan pengambilan keputusan.

2) Menunjang proses perencanaan. Perencanaan merupakan suatu proses kegiatan untuk memperkirakan kondisi yang akan dating, yang akan dicapai. Upaya pencapaian ini akan dilaksanakan melalui serangkaian kegiatan yang telah ditentukan dalam perencanaan. Untuk menyusun rencana, dibutuhkan banyak informasi yang mendukung tercapainya tujuan. Informasi itu dapat diperoleh dari arsip.

3) Mendukung pengawasan. Dalam melakukan pengawasan, dibutuhkan informasi terekam tentang rencana yang telah disusun, hal-hal yang telah disusun, hal-hal yang belum dilaksanakan. Semuanya direkam dalam bentuk arsip.

4) Sebagai alat pembuktian. Institusi pengadilan akan menghasilkan banyak informasi terekam yang dapat digunakan kembali oleh pengadilan tersebut. Seluruh informasi ini merupakan arsip yang dapat digunakan dalam proses pembuktian.

5) Sebagai memori organisasi. Seluruh kegiatan organisasi, baik berupa transaksi, aktivitas internal, maupun keluaran yang dibuat organisasi dapat direkam dalam bentuk arsip. Informasi terekam ini dapat digunakan oleh organisasi dalam menjalankan kegiatanya pada masa yang akan datang.

6) Dapat digunakan untuk kepentingan politik dan ekonomi. Kegiatan politk dan ekonomi akan menghasilkan dan membutuhkan informasi. Beragam informasi ini diperoleh dari berbagai sumber dan salah satunya berasal dari arsip.

b) Pembagian Arsip

Berdasarkan fungsinya, arsip dibagi menjadi dua yaitu, arsip dinamis dan arsip statis. Adapun pengertian dari kedua arsip tersebut adalah sebagai berikut:

1) Arsip dinamis adalah arsip yang masih diperlukan secara langsung dalam perencanaan, pelaksanaan, dan penyelenggaraan kehidupan kebangsaan pada umumnya atau arsip yang digunakan secara langsung dalam penyelenggaraan administrasi negara (Mulyadi, 2016:32). Sedangkan menurut Menurut Muhidin dan Winata (2016:5) yang termasuk dalam arsip dinamis, yaitu:

(a) Arsip vital, yaitu arsip yang keberadaanya merupakan persyaratan dasar bagi kelangsungan operasional pencipta arsip, tidak dapat diperbaharui, dan tidak tergantikan apabila rusak atau hilang.

(b) Arsip aktif, yaitu arsip yang frekuensi penggunaannya tinggi atau terus-menerus.

(c) Arsip inaktif, yaitu arsip yang frekuensi penggunaannya telah menurun.

Dari pengertian di atas dapat disimpulkan bahwa yang dimkasud dengan arsip dinamis adalah informasi terekam yang dibuat atau diterima oleh suatu organisasi dan masih digunakan secara langsung dalam kegiatan organisasi.

2) Arsip Statis adalah arsip yang dihasilkan oleh pencipta arsip karena memiliki nilai guna kesejarahan, telah habis retensinya, dan berketerangan dipermanenkan yang telah diverifikasi, baik secara langsung maupun tidak langsung oleh Arsip Nasional Republik Indonesia (ANRI) dan atau lembaga kearsipan (Muhidin dan Winata, 2016:5). Sedangkan menurut Mulyadi (2016:34), Arsip statis yaitu arsip yang tidak dipergunakan lagi secara langsung dalam perencanaan, pelaksanaan, atau penyelenggaraan administrasi perkantoran, atau sudah tidak dipakai lagi dalam kegiatan perkantoran sehari-hari. dari dua penegrtian di atas, dapat diambil kesimpulan, yang dimaksud dengan arsip statis adalah arsip yang tidak lagi digunakan secara langsung dalam proses berjalanya suatu organisasi.

Dapat digunakan untuk kepentingan politik dan ekonomi. Kegiatan politk dan ekonomi akan menghasilkan dan membutuhkan 
informasi. Beragam informasi ini diperoleh dari berbagai sumber dan salah satunya berasal dari arsip.

2. Konsep Pengelolaan Arsip Dinamis dan Statis

Peraturan Pemerintah Republik Indonesia Nomor 28 Tahun 2012 Bab Satu, Pasal 1 Ayat 20-21, tentang Pelaksanaan Kegiatan Kearsipan, yakni "pengelolaan arsip baik arsip dinamis maupun arsip statis adalah proses pengendalian arsip secara efisien, efektif, dan sistematis meliputi penciptaan, penggunaan, dan pemeliharaan, serta penyusutan arsip". Diaturnya pengelolaan arsip dalam Peraturan Pemerintah menunjukan bahwa pengelolaan arsip tidak dapat dilakukan dengan sembarangan. Pengelolaan arsip dalam penelitian ini lebih berfokus pada daur hidup arsip (life cycle of records), yaitu dimulai dari penciptaan atau penerimaan, penggunaan atau pemanfaatan, pemeliharaan dan penyimpanan, penemuan kembali arsip dan disposisi akhir untuk menentukan masa simpan arsip apakah arsip dilestarikan (reservation) karena mempunyai nilai permanen atau dimusnahkan (destruction) karena sudah tidak memiliki nilai guna serta penyusutan arsip.

a. Asas Pengelolaan Arsip

Pengelolaan arsip dalam suatu kebijakan menggunakan asas, yang secara umum digunakan agar pengaturan arsip dan penanggungjawabnya dapat diketahui. Dengan kata lain, arsip memerlukan pengorganisasian arsip secara jelas sehingga dapat dilaksanakan sebaik-baiknya dalam suatu organisasi. Ada beberapa pengorganisasian arsip dalam kantor yang sudah dikenal menurut Sugiarto dan Wahyono (2015:19-20) yaitu;

1) Sentralisasi, adalah sistem pengelolaan arsip yang dilakukan secara terpusat dalam suatu organisasi, atau dengan kata lain penyimpanan arsip yang dipusatkan di satu unit kerja khusus yang lazim disebut sentral arsip. Dengan sentralisasi arsip maka semua surat-surat kantor yang sudah selesai diproses akan disimpan di sentral arsip. Keuntungan dari sentralisasi arsip:

2) Ruang atau tempat penyimpanan, tenaga dan peralatan arsip dapat dihemat, karena dalam satu organisasi terdapat satu tempat pengelolaan atau penyimpanan arsip.

3) Karena menjadi unit khusus, maka petugas dapat mengonsentrasikan diri khusus pada pekerjaan kaearsipan

4) Tidak adanya duplikasi arsip, karena kantor hanya menyimpan 1 (satu) arsip.

5) istem penyimpanan dari berbagai arsip dapat diseragamkan, sehingga sistem penyimpanan atau penggolongan arsip lebih sederhana.

6) Desentralisasi, yaitu pengelolaan arsip yang dilakukan pada setiap unit kerja dalam suatu organisasi. Maksudnya, bila suatu kantor atau organisasi menganut sistem desentralisasi, ini berarti bahwa semua unit mengelola arsipnya masing-masing. Sistem ini akan lebih menguntungkan bila diterapkan pada suatu organisasi yang relatif besar. Keuntungan pada desentralisasi arsip adalah:

(a) Pengelolaan arsip dapat dilakukan sesuai kebutuhan unit kerja masingmasing.

(b) Keperluan akan arsip mudah terpenuhi, karena berada dalam kerja sendiri, sehingga relatif dapat dijangkau dengan mudah dan cepat.

(c) Penangan arsip lebih mudah dilakukan, karena arsipnya sudah dikenal.

Namun demikian, dalam asas sentralisasi memiliki kerugian yaitu: sistem sentralisasi arsip hanya efisien dan efektif untuk organisasi yang kecil, tidak semua jenis arsip dapat disimpan dengan satu sistem penyimpana yang seragam, unit kerja yang memerlukan arsip akan memakan waktu lebih lama untuk memperoleh arsip yang diperlukan. sedangkan yang menggunakan asas desentralisasi memiliki kerugian yaitu: penyimpanan arsip tersebar diberbagai lokasi, dan dapat menimbulkan duplikasi arsip yang disimpan. Kemudian kantor harus menyediakan peralatan dan perlengkapan arsip disetiap unit kerja, sehingga penghematan pemakaian peralatan dan perlangkapan sukar dijalankan. Penataran dan latihan kearsipan perlu diadakan karena diadakan karena petugas-petugas umumnya bertugas rangkap dan tidak punya latar belakang Pendidikan kearsipan. Dan kegiatan 
pemusnahan arsip harus dilakukan oleh setiap unit kerja, hal ini merupakan pemborosan.

\section{Tujuan Pengelolaan Arsip}

Setiap kegiatan dalam suatu organisasi, baik organisasi pemerintah maupun swasta selalu ada kaitannya dengan masalah arsip. Arsip mempunyai peranan penting dalam proses penyajian informasi, oleh sebab itu untuk dapat menyajikan informasi yang lengkap, cepat dan benar haruslah ada sistem dan prosedur kerja yang baik di bidang kearsipan. Tujuan diadakannya pengelolaan arsip menurut UU No. 7 tahun 1971 pasal 3 (Basir barthos, 2016:12) adalah Tujuan kearsipan adalah untuk menjamin keselamatan bahan pertanggungjawaban nasional tentang perencanaan, pelaksanaan dan penyelenggaraan kehidupan kebangsaan serta untuk menyediakan bahan pertanggungjawaban tersebut bagi kegiatan pemerintah. Dari pengertian tersebut dapat dipahami bahwa arti pentingnya kearsipan memiliki jangkauan yang sangat luas, yaitu baik sebagai alat untuk membantu daya ingatan manusia maupun dalam rangka pelaksanaan kegiatan pemerintahan dan pelaksanaan kehidupan kebangsaan. Mengingat pentingnya peranan pengelolaan arsip, maka untuk melaksanakan tugas pemerintahan dan tugas pembangunan dengan baik diperlukan usaha peningkatan dan penyempurnaan pengelolaan arsip secara optimal agar dapat berfungsi dengan baik, berdaya guna dan tepat guna.

\section{Penyusutan Arsip}

Arsip yang terus berkembang setiap hari akan menjadi tumpukan arsip, apabila dibiarkan begitu saja tentu akan membutuhkan tempat yang lebih luas dalam hal penyimpanan arsip, sehingga terjadi pemborosan tempat. Oleh karena itu penyusutan arsip merupakan kegiatan yang penting dalam proses pengelolaan arsip dalam suatu lembaga atau organisasi. Penyusutan arsip adalah kegiatan pengurangan arsip yang disebabkan oleh frekuensi penggunanya telah menurun atau jarang digunakan dan sudah tidak bernilai guna. (Muhidin dan Winata, 2018:35). Arsip yang disimpan oleh suatu lembaga memiliki nilai guna yang jangka waktunya berbeda-beda. Ada arsip yang memiliki nilai kegunaan abadi serta ada yang dimiliki kegunaan jangka waktu tertentu. Sebagian besar arsip yang disimpan oleh lembaga memiliki nilai kegunaan yang jangka waktunya terbatas, oleh karena itu arsip semacam itu suatu ketika harus disusut.

Penyusutan arsip juga digunakan untuk menilai arsip berdasarkan jenisnya, fisiknya, maupun informasi. Penilaian arsip (terutama dari segi informasinya) adalah sangat penting dalam rangka menentukan tindakan penyusutan selanjutnya. Secara berkala nilai kegunaan setiap warkat yang disimpan sebagai arsip perlu ditentukan sehingga petugas arsip dapat menentukan kapan warkat yang bersangkutan dapat disusut. Warkat atau arsip yang memperoleh prioritas untuk disusut terlebih dahulu adalah warkat atau arsip yang mempunyai nilai guna paling kecil. Arsip yang disusut adalah arsip yang sudah tidak dibutuhkan lagi (Syahruramadhan, 2017:29).

Berdasarkan pendapat tersebut dapat disimpulkan bahwa jadwal retensi merupakan daftar yang berisi tentang jangka waktu penyimpanan arsip yang dipergunakan sebagai pedoman kebijaksanaan penyusutan arsip. jadwal retensi dibuat oleh masing-masing organisasi yang disesuaikan dengan jenis arsip yang disimpan dan telah diidentifikasi menurut golongan yaitu arsip vital, arsip penting, arsip berguna, dan arsip tidak berguna.

\section{Pengelolaan Arsip Statis}

Pengelolaan arsip statis adalah proses pengendalian arsip statis secara efisien, efektif dan sitematis yang meliputi akuisisi, pengolahan, preservasi, pemanfaatan, pendayagunaan dan pelayanan publik dalam suatu sistem kearsipan nasional (Muhidin dan Winata, 2018:302).

Menurut Perka ANRI No.31 Tahun 2011 pengelolaan arsip statis meliputi (Muhidin dan Winata, 2018:302):

a) Akuisisi arsip statis adalah proses penambahan khazanah arsip statis pada lembaga kearsipan yang dilaksanakan melalui kegiatan penyerahan arsip statis dan hak pengolahanya dari pencipta arsip kepada lembaga kearsipan. 
b) Pengolahan arsip statis merupakan kegiatan menata informasi arsip statis, menata fisik arsip statis, dan penyususnan sarana bantu temu balik arsip statis.

c) Preservasi arsip statis adalah keseluruhan proses dan kerja dalam rangka perlindungan arsip terhadap kerusakan arsip atau unsur perusak dan restorasi atau perbaikan (reparasi) bagian arsip yang rusak.

d) Akses arsip statis adalah ketersediaan arsip sebagai hasil dari kewenangan hukum dan otoritas legal serta keberadaan sarana bantu untuk mempermudah penemuan dan pemanfaatan arsip.

\section{B. Kerangka Pikir}

Arsip bagian yang tidak dapat dipisahkan di dalam organisasi baik organisasi pemerintah atau organisasi swasta, salah satunya adalah organisasi pendidikan yaitu sekolah atau madrasah. Arsip dilihat dari fungsinya dibagi menjadi dua yaitu arsip dinamis dan arsip statis. Arsip dinamis adalah informasi terekam yang dibuat atau diterima oleh suatu organisasi dan masih digunakan secara langsung dalam kegiatan organisasi. Adapun arsip statis adalah arsip yang tidak lagi digunakan secara langsung dalam proses berjalanya suatu organisasi.

Keadaan arsip pada setiap organisasi selalu mengalami kenaikan jumlah volumenya sehingga perlu dikelola dengan baik, pengelolaan arsip dikatakan baik ketika arsip tersebut tertata rapih, tidak rusak dan mudah ditemukan kembali. Pengelolaan arsip yang baik harus didukung oleh sistem penyimpanan arsip yang sesuai, fasilitas kearsipan yang memenuhi syarat, tenaga-tenaga dalam bidang kearsipan yang memadai, dan lingkungan kerja yang baik untuk arsip. Kegiatan pengelolaan arsip dinamis dan statis meliputi kegiatan penciptaan, penggunaan, pemeliharaan dan penyusutan. Pengelolaan arsip dinamis dan statis perlu untuk dilakukan karena memiliki peranan yang sangat penting dalam suatu organisasi, yaitu sebagai bahan pertimbangan pengambilan keputusan secara tepat, sebagai bahan pertanggungjawaban, dan sebagai alat pengawasan dalam rangka melaksanakan berbagai kegiatan pengembangan manajemen.
Di dalam pengelolaan arsip yang baik, tentu disana ada kelebihan dan kekurangan dalam sistem pengelolaanya, karena setiap proses yang dilakukan tidak ada yang memiliki kesmpurnaan. Kerangka pikir penelitian tersebut dapat digambarkan secara ringkas sebagai berikut:

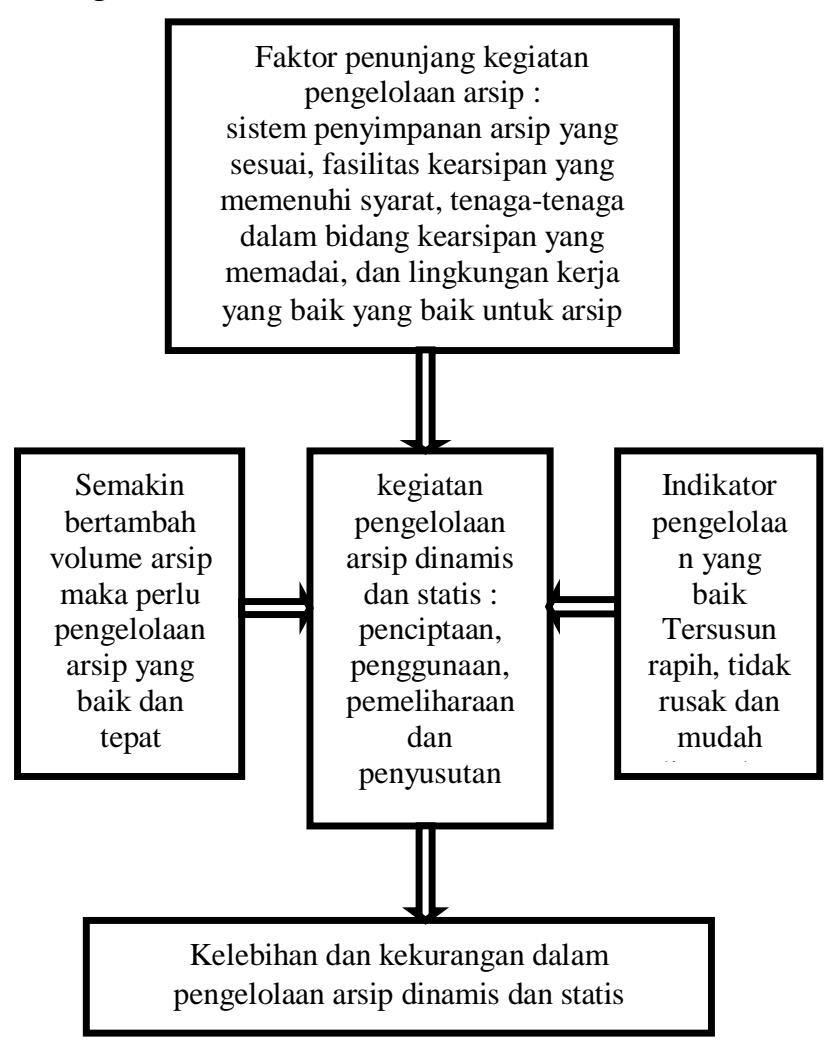

Gambar 1: kerangka pikir

\section{BAB III METODOLOGI PENELITIAN}

\section{A. Metode Penelitian}

Metode penelitian yang digunakan oleh penulis pada sekripsi ini adalah metode deskriptif. Metode deskriptif adalah Suatu penelitian yang dilakukan untuk mengetahui nilai variabel mandiri, baik satu variabel atau lebih (independen) tanpa membuat perbandingan atau menghubungkan dengan variabel lain. Metode ini dipilih oleh penulis karena data-data yang diperlukan untuk menjawab rumusan masalah di atas yang bersifat deskriptif, apa adanya dan sesuai dengan variabel yang diteliti.

Adapun pendekatannya menggunakan pendekatan kualitatif. Pendekatan kualitatif itu sendiri adalah pendekatan yang dimaksudkan untuk memahami fenomena tentang apa yang dialami oleh subjek penelitian misalnya 
perilaku, persepsi, motivasi, tindakan disajikan dengan cara deskripsi dalam bentuk kata-kata dan bahasa, pada suatu kontek khusus yang alamiah dengan memanfaatkan metode alamiah (Lexy J Moleong, 2016:6). Berdasarkan pendapat tersebut maka penulis tetapkan penelitian ini menggunakan pendekatan kualitatif dengan alasan agar dapat melakukan penelitian sesuai dengan fenomena yang sedang terjadi saat itu. Sehingga peneliti ingin menggambarkan fenomena yang berkaitan dengan pengelolaan arsip dinamis dan statis di MTs N 2 Pringsewu dan selanjutnya akan dianalisis untuk mengetahui apa kelebihan dan kekurangan dari pengelolalaan arsip yang ada di Madrasah tersebut.

\section{B. Definisi Operasional Variabel}

Di dalam penelitian ini, peneliti melakukan penelitian terkait dengan pengelolaan arsip baik arsip dinamis maupun statis. Yang dimaksud dengan pengelolaan disini adalah pengurusan arsip dari mulai penciptaan, penggunaan, pemeliharaan dan penyusutan. Penciptaan adalah kegiatan membuat surat dan dokumen atau naskah lain yang diperlukan dalam rangka penyelenggaraan organisasi untuk mencapai tujuan. Sedangkan penggunaan adalah proses pemakaian arsip untuk kepentingan organisasi dalam kegiatan sehari-hari seperti peminjaman, pengembaalian dan lain sebagainya. Sedangkan pemeliharaan adalah usaha penjagaan arsip agar kondisi fisiknya tidak rusak selama masih mempunyai nilai guna. Dan yang dimaksud dengan penyusutan adalah kegiatan pengurangan arsip dengan berbagai cara yang digunakan. Sedangkan arsip yang dikelola mencakup arsip diamis dan statis, adapun arsip dinamis adalah informasi terekam yang dibuat atau diterima oleh suatu organisasi dan masih digunakan secara langsung dalam kegiatan organisasi, dan arsip setatis adalah arsip yang tidak dipergunakan secara langsung untuk perencanaan, pelaksanaan dan penyelenggaraan kehidupan kebangsaan pada umumnya. Jadi arsip yang akan diteliti oleh penulis adalah tidak hanya terbatas pada arsip yang berbentuk surat namun segala arsip yang berkaitan dengan dokumen-dokumen penting yang ada di MTs N
2 pringsewu yang menjadi harta dan hidup berlangsungnya organisasi pendidikan tersebut.

\section{Metode Pengumpulan Data}

Tahap berikutnya adalah pengumpulan data. Agar mendapatkan data yang akurat, valid dan dapat dipertanggung jawabkan keabsahannya, peneliti menggunakan metode pengumpulan data yang sesuai dengan data yang akan dicari guna menjawab rumusan masalah diatas, adapun metode pengumpulan data yang digunakan adalah observasi, wawancara dan dokumentasi.

1. Observasi ini digunakan untuk mengamati proses pengelolaan arsip baik arsip dinamis maupun statis. Adapun yang menjadi objek penelitian adalah para pegawai tata usaha yang ada di MTs N 2 Pringsewu, yang mengemban tugas di dalam mengelola arsip.

2. Bentuk wawancara yang diunakan oleh penulis adalah wawancara semi tersetruktur. Wawancara semiterstruktur merupakan wawancara yang pelaksanaannya lebih bebas dibanding wawancara terstruktur. Data hasil wawancara berfungsi untuk memperkuat data yang dihasilkan dari obervasi. Adapun informan yang akan diwawancara adalah kepala sekolah, kepala Tata Usaha serta para pegawai Tata Usaha MTs N 2 Pringsewu yang bertugas dibidang kerasipan.

3. Metode Dokumentasi ini digunakan untuk mencari data terkait dengan proses pengelolaan arsip dinamis dan statis di MTs $\mathrm{N} 2$ Pringsewu dan data-data lain yang diperlukan guna menjawab rumusan masalah yang ada pada penelitian ini. Data ini berfungsi untuk memperkuat data yang dihasilkan dari obseravsi dan wawancara, sehingga data semakin valid.

\section{Instrumen Penelitian}

Dalam penelitian kualitatif, yang menjadi instrumen atau alat penelitian adalah peneliti itu sendiri, oleh karena itu peneliti sebagai instrumen juga harus divalidasi seberapa jauh peneliti siap untuk melakukan penelitian yang selanjutnya akan terjun secara langsung ke lapangan. Adapun validasi terhadap peneliti sebagai instrumen meliputi validasi terhadap pemahaman metode penelitian kualitatif, 
penguasaan wawasan terhadap bidang yang diteliti, kesiapan peneliti untuk memasuki obyek penelitian, baik secara akademik maupun logistiknya. Instrumen yang digunakan peneliti adalah pedoman wawancara, lembar observasi (Chek list) dan daftar cocok.

\section{E. Populasi, Sampel dan Teknik Pengambilan Sampel}

1. Populasi

Populasi adalah wilayah generalisasi yang terdiri atas; obyek/subyek yang mempunyai kualitas dan karakteristik tertentu yang ditetapkan oleh peneliti untuk dipelajari dan kemudian ditarik kesimpulannya (Sugiyono, 2016:80). Populasi yang dijadikan sebagai objek penelitian ini adalah pegawai Tata Usaha (TU) MTs N 2 Pringsewu yang berjumlah 8 orang.

\section{Sampel}

Sesuai dengan teori di atas, karena jumlah populasi hanya sedikit dan subjeknya meliputi semua yang ada dalam populasi, maka jumlah populasi tersebut dijadikan sebagai sampel yaitu jumlah pegawai Tata Usaha yang ada di MTs N 2 Pringsewu ada 8 orang, sehingga semua dijadikan sebagai sampel dalam penelitian ini.

\section{F. Metode Analisis Data}

Analisa data adalah suatu proses mencari dan menyusun secara sistematis data yang diperoleh dari hasil wawancara, observasi, dan dokumentasi dengan cara mengorganisasikan data ke dalam kategori, dijabarkan ke unit-unit, melakukan sintesa, menyusun ke dalam pola, memilih mana yang penting dan akan dipelajari dan membuat kesimpulan.

Adapun tahapan-tahapan analisis data menurut Miles dan Huberman dalam Sugiyono (2016:247-252) adalah sebagai berikut:

1. Reduksi data, yaitu data yang diperoleh dari lapangan yang banyak dan kompleks, maka perlu dilakukan analisis data melalui reduksi data. Mereduksi data dengan cara merangkum, memilih hal-hal pokok, memfokuskan hal-hal yang penting dan membuang hal-hal yang dianggap kurang penting. Dengan demikian data yang direduksi dapat memberi gambaran yang jelas bagi peneliti untuk mendapat data selanjutnya.

2. Penyajian data, yaitu data yang direduksi disajikan dalam bentuk uraian singkat berupa teks yang bersifat naratif. Melalui penyajian data tersebut maka data akan mudah dipahami sehingga memudahkan rencana kerja selanjutnya.

3. Penarikan kesimpulan, yaitu data yang sudah disajikan dianalisis secara kritis berdasarkan fakta-fakta yang diperoleh di lapangan. Penarikan kesimpulan dilakukan dalam bentuk naratif sebagai jawaban dari rumusan masalah yang dirumuskan sejak awal.

Ketiga komponen analisis di atas dilakukan dengan cara interaktif yaitu saling berhubungan selama dan sesudah pengumpulan data. Proses analisis data ini mengalir (flow), sehingga tidak menjadi kaku dari tahap awal sampai tahap akhir penelitian. Data yang peneliti dapatkan akan dianalisis berdasarkan pada variable penelitian yang telah ditentukan.

Untuk memperjelas, berikut gambar analisis data kualitatif menurut Miles dan Huberman:

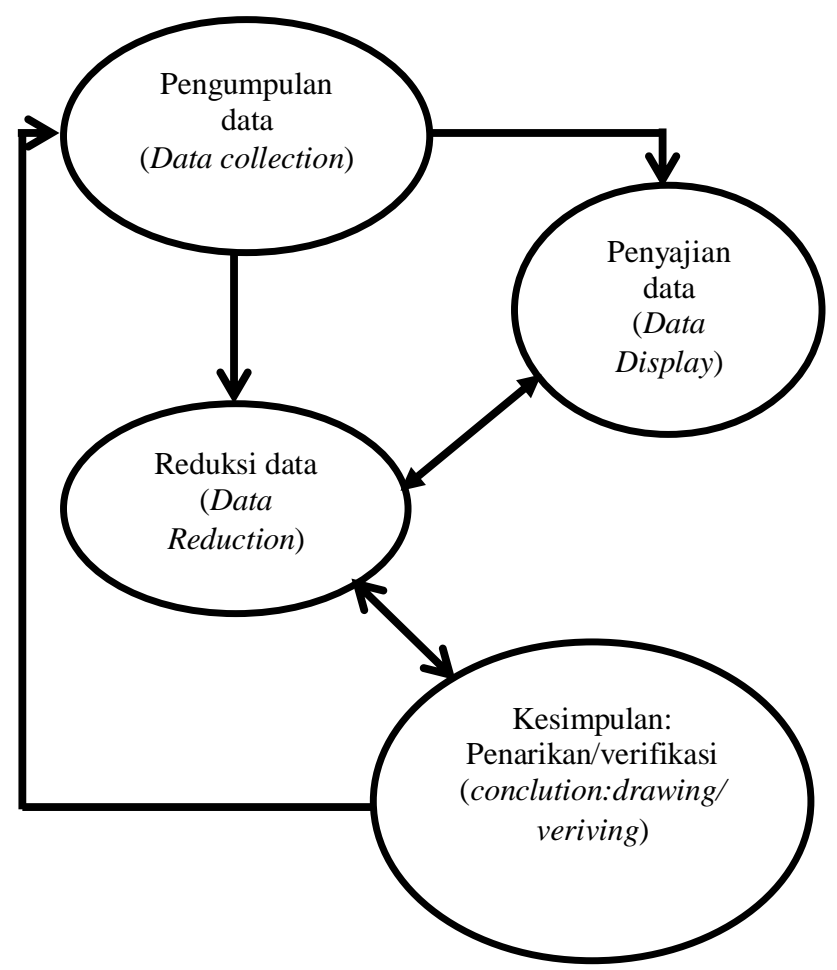

Gambar 1: Komponen dalam Analisis Data (Model Interaktif dari Miles dan Huberman) 


\section{BAB IV HASIL DAN PEMBAHASAN}

\section{A. Sejarah Singkat}

MTs. N. 2 Pringsewu adalah salah satu Madrasah yang terdapat di Pekon Sukamulya, kecamatan Banyumas, Kabupaten Pringsewu, tepatnya terletak di jalan Abdul Karim, Pekon Sukamulya, Kecamatan Banyumas, Kabupaten Pringsewu. Madrasah ini didirikan untuk menanggulangi adanya putus Madrasah dan meningkatkan pendidikan di bidang agama islam, karena sebelumya sudah ada Madrasah menegah pertama (SMP) saja. Oleh karena itu didirikannya SMP yang bercirikhas Islam yaitu madrasah tsanawiyah. MTs. N. 2 Pringsewu ini berdiri tahun 1983, awalnya bangunan Madrasah ini milik pribadi, sedangkan tanah yang menjadi lokasi bangunan MTs ini adalah hibah atau pemberian dari ibu $\mathrm{Hj}$. Iroh yang selanjutnya Madrasah inipun diberi nama MTs. Al Hikmah yang sebelumnya bernama MTs persiapan. Kemudian pada tanggal 17 Maret 1997 dengan nomor NSM 21.1.18.01.07.007. Madrasah Madrasah Tsanawiyah ini menjadi negeri. Sejak diresmikannya MTs Al-Hikmah menjadi Madrasah negeri maka sejak saat itu sampai sekarang MTs Al Hikmah dikenal dengan MTs. N. Sukoharjo. Pada tanggal 17 November 2009, Badan Akreditasi Madrasah /Madrasah (BAN-SM) menetapkan bahwa MTs. N. Sukoharjo dengan NSS/NIS/NSM: 21.1.18.01.07.007 alamat jalan Abdul Karim, Desa Sukamulya, Kecamatan Banyumas, kabupaten Pringsewu dengan Akreditasi B. Setelah Pringsewu menjadi kabupaten sendiri, maka saat itu nama MTs N sukoharjo berubah menjadi MTs N 2 Pringsewu. Sesui dengan surat keputusan yang dikeluaran oleh Badan Akreditasi Sekolah/Madrasah dengan nomor 580/BAN-SM/SK/2019 pada tanggal 02 juli 2019 lalu bahwa Sekolah ini mendapat Akreditas A.

MTs. N. 2 Pringsewu terletak di daerah pedesaan. Keadaan alamnya merupakan dataran rendah degan luas lokasi $4830 \mathrm{~m}$ dan luas bangunan $953 \mathrm{~m}$. Adapun jarak MTs N 2 Pringsewu ke pusat Kecamatan adalah $12 \mathrm{KM}$. MTs N 2 Pringsewu termasuk Madrasah yang mudah dijangkau, karena letaknya setrategis dari pusat kota Pringsewu dengan waktu kurang lebih 30 menit. MTs N 2 Pringsewu terletak di pinggir jalan, tepatnya di jalan Abdul Karim, Pekon Sukamulya, Kecamatan Banyumas, Kabupaten Pringsewu, dengan setatus tanah wakaf/sertifikat dengan luas tanah $4830 \mathrm{~m}$ dan luas bangunan $953 \mathrm{~m}$.

\section{B. Pengumpulan Dan Penyajian Data}

1. Pengelolaan Arsip Dinamis di MTs N 2 Pringsewu

a. Penciptaan Arsip Dinamis

Berdasarkan hasil wawancara dengan kepala Tata Usaha yaitu bapak Iskandarsyah S.H diperoleh data terkait dengan pengelolaan arsip dinamis di Bagian Tata Usaha Madrasah Tsanawiyah Negeri 2 Pringsewu bahwa arsip yang disimpan kebanyakan berupa surat, baik surat masuk maupun surat keluar, SPJ gaji, data kepegawaian seperti SK atau Surat Keputusan, data kesiswaan baik data lulusan atau data siswa yang masih aktif di sekolah, data ini disimpan dalam bentuk buku induk, dan datadata yang lain seperti absen pegawai tata usaha, absen guru serta surat berharga lainya. Hal ini sesuai dengan apa yang disampaikan oleh kepala Tata Usaha sebagai berikut: "iya, jadi bentuk-bentuk arsip yang dikelola di bagian tata usaha ya kebanyakan dalam bentuk surat menyurat baik itu surat masuk atau surat keluar, Surat Keputusan atau SK, absen pegawai, absen guru, data-data siswa baik yang masih aktif atau data lulusan dan surat berharga lainya seperti akta wakaf tanah, surat ijin pendirian bangunan, dan lain sebagainya".

Hasil wawancara dengan bagian surat menyurat yaitu ibu Lela Handriyani, A.Md yang berkaitan dengan penciptaan arsip dari bagian surat menyurat yaitu pengurusan surat masuk dan pengurusan surat keluar. Untuk proses pengelolaan surat masuk, sebagaimana yang diungkapkan oleh ibu Lela Handriyani, A.Md di Bagian Tata Usaha Madrasah Tsanawiyah Negeri 2 Pringsewu yang bertanggungjawab dibagian surat-menyurat bahwa:

"Pertama surat masuk diterima oleh staf bagian tata usaha khususnya distaf bagian suratmenyurat, kemudian surat tersebut disortir atau digolongkan ke dalam surat dinas, surat resmi, dan lain-lain. Surat yang hanya boleh dibuka hanyalah surat yang bersifat 
kedinasan/ditujukan untuk Madrasah . selanjutnya surat dicatat ke dalam buku agenda surat masuk, Surat diberi lembar disposisi. Surat beserta lembar disposisi yang telah diisi sebelumnya oleh petugas, kemudian diserahkan kepada Kepala Madrasah untuk dimintakan disposisi. Surat dikirim sesuai dengan disposisi Kepala Madrasah untuk ditindak lanjuti dan kemudian surat masuk dikembalikan lagi ke TU untuk diarsipkan".

Dari hasil wawancara tersebut diatas, dapat disimpulkan bahwasanya dalam penciptaan arsip surat, yang berkaitan dengan surat masuk adalah sebagai berikut:

1) Pertama surat masuk diterima oleh staf bagian tata usaha.

2) Surat kemudian disortir atau digolongkan ke dalam surat dinas, surat resmi, dan lain-lain. Surat yang hanya boleh dibuka hanyalah surat yang bersifat kedinasan/ditujukan untuk Madrasah .

3) Surat dicatat ke dalam buku agenda surat masuk.

4) Surat diberi lembar disposisi.

5) Surat beserta lembar disposisi yang telah diisi sebelumnya oleh petugas, kemudian diserahkan kepada Kepala Madrasah untuk dimintakan disposisi.

6) Surat dikirim sesuai dengan disposisi Kepala Madrasah untuk ditindak lanjuti dan kemudian surat masuk dikembalikan lagi ke TU untuk diarsipkan.

Adapun untuk kegiatan pengurusan surat keluar yang dilakukan di Bagian Madrasah Tsanawiyah Negeri 2 Pringsewu sebagaimana yang disampaikan oleh ibu Lela Handriyani, A.Md adalah sebagai berikut: "Surat yang akan dikirim dikonsep terlebih dahulu oleh operator sekolah yaitu bapak Kurnia, S.Kom, kemudian dikonsultasikan kepada pihak yang berkepentingan/pimpinan yang mengirim surat, selanjutnya surat yang sudah dicek oleh pimpinan atau yang bersangkutan dicetak oleh operator sekolah dan kemudian dimintakan tanda tangan Kepala Madrasah, Setelah mendapat tanda tangan Kepala Madrasah, Surat tersebut dicatat dalam buku agenda surat keluar dengan mengisikan kode surat, nomor agenda, hal, alamat tujuan surat, dan pengelola surat oleh bagian surat -menyurat. Surat yang telah selesai dicatat dalam buku agenda surat keluar, siap dikirim dan didistribusikan sesuai alamat, serta tidak lupa meminta tanda penerima surat dalam buku ekspedisi”.

Hasil wawancara diatas diperkuat oleh pak Kurnia, S.Kom selaku operator sekolah, beliau mengatakan: "Apabila sekolah ada kepentingan terkait dengan pembuatan surat-menyurat, langsung berhubungan dengan saya, selanjtnya saya konsep surat tersebut, lalu dikonsultasikan ke kepala madarasah untuk dicek, setelah itu baru saya cetak dan saya mintakan tanda tangan kepala madrasah baru saya serahkan ke bagian surat-menyurat untuk dimintakan nomor surat dan lain-lain".

Hasil wawancara terkait dengan pengurusan surat keluar tersebut, dapat disimpulkan sebagai beriku:

1) Surat yang akan dikirim dikonsep terlebih dahulu, kemudian dikonsultasikan kepada pihak yang berkepentingan/pimpinan yang mengirim surat.

2) Mencetak surat yang telah dikonsep dan dikonsultasikan.

3) Surat yang telah dicetak, kemudian dimintakan tanda tangan Kepala Madrasah Tsanawiyah Negeri 2 Pringsewu.

4) Setelah mendapat tanda tangan Kepala Madrasah, Surat tersebut dicatat dalam buku agenda surat keluar dengan mengisikan kode surat, nomor agenda, hal, alamat tujuan surat, dan pengelola surat.

5) Surat yang telah selesai dicatat dalam buku agenda surat keluar, siap dikirim dan didistribusikan sesuai alamat, serta tidak lupa meminta tanda penerima surat dalam buku ekspedisi.

\section{Pembahasan Hasil Penelitian}

Berdasarkan hasil penelitian dan hasil analisis tentang data pengelolaan arsip dinamis dan statis di MTs N 2 Pringsewu, yang meliputi penciptaan, penggunaan, pemeliharaan dan penyusutan untuk arsip dinamis, adapun untuk arsip statis meliputi akusisi, penglahan, preservasi, dan akses arsip sebagai berikut:

1) Penciptaan Arsip Dinamis di Bagian Tata Usaha MTs N 2 Pringsewu, Pengelolaan arsip dinamis di Bagian Tata Usaha MTs N 
2 Pringsewu menggunakan pedomanpedoman seperti Keputusan Menteri Pendidikan dan Kebudayaan Republik Indonesia Nomor 091/U/1995 tentang Pedoman Tata Persuratan dan Kearsipan di Lingkungan Departemen Pendidikan dan Kebudayaan. Penciptaan arsip yang ada di MTs N 2 Pringsewu lebih pada penciptaan pada Surat Keluar dan Surat Masuk. Untuk penanganan surat masuk dan keluar digunakan beberapa alat bantu seperti buku agenda, lembar disposisi, dan buku ekspedisi.

2) Pengunaan Arsip Dinamis di MTs $\mathrm{N} 2$ Pringsewu, Proses peminjaman arsip yang dilakukan di Bagian Tata Usaha MTs N 2 Pringsewu belum berjalan dengan baik karena dalam peminjaman arsip tidak menggunakan prosedur khusus dan belum adanya buku peminjaman arsip. Dengan tidak adanya prosedur khusus dapat mengakibatkan arsip hilang atau tercecer. Karena proses peminjaman arsip hanya bersifat lisan, yaitu dari yang berkepentingan meminjam arsip lalu lapor ke kepala bagaian tata usaha setelah itu baru ke bagian yang bertanggungjawab terhadap arsip yang dibutuhan. Disamping itu tidak terdapatnya buku pinjam arsip atau kartu pinjam arsip mengakibatkan tidak adanya kontrol untuk mengantisipasi hilangnya arsip atau tidak dikembalikannya arsip.

3) Proses penemuan kembali arsip dinamis yang berupa surat masuk dan surat keluar, SPJ gaji, dan SK/Surat Keputusan di Bagian Tata Usaha MTs N 2 Pringsewu hanya dengan melihat keterangan yang tertulis dalam lemari penyimpanan dan map ordner akan menyebabkan proses penemuan arsip yang dicari cukup efektif dan efisien. Hal ini terlihat dari pelaksanaan penemuan kembali arsip yang dicari oleh petugas arsip membutuhkan waktu kurang lebi 1 menit dan sudah cukup memudahkan pencarian, karena proses pencarian bisa fokus di satu tempat.

4) Salah satu bentuk pemeliharaan arsip yaitu penyimpanan, Penggunaan sistem. Penyimpanan mutlak dilakukan suatu kantor dalam bidang kearsipan. Secara teoritis tidak ada suatu sistem yang paling baik untuk digunakan dalam suatu kantor. Sistem penyimpanan yang baik yaitu sistem yang sesuai dengan karakteristik arsip yang dimiliki masing-masing kantor.

Berdasarkan hasil analisis diatas dapat disimpulkan, bahwa pengelolaan arsip dinamis dan statis di MTs N 2 Pringsewu, yang notabenenya dilihat dari latar belakang pegawai tata usaha MTs N 2 Pringsewu tidak ada yang mempunyai latar belakang pendidikan tentang kerasipan adalah sebagai berikut:

1) Secara keseluruhn pengelolaan arsip dinamis dan statis sudah sesuai dengan undangundang kearsipan.

2) Tempat penyimpanan arsip menggunkan azaz desentralisasi dan diletakan di samping meja kerja pegawai yang bertanggungjawab dengan kearasipan masing-masing.

3) Sistem penyimpanan arsip dengan menggunkan sistem kronologi, sehingga memudahkan dalam pencarian arsip dari tahun ke tahun.

4) Adanya sistem pendeskripsia arsip, sehingga arsip dapat terseusun sesuai dengan golongan arsip.

Kekurangan Pengelolaan Arsip Dinamis dan Statis di MTs N 2 Pringsewu, Pengelolaan arsip yang telah dilakukan oleh MTs N 2 Pringsewu, memiliki kekurangan sebagai berikut:

1) Tidak ada ruangan khusus penyimpanan arsip

2) Masih ada sebagian tempat penyimpanan arsip yang terbuat dari kayu, sehingga masih rawan dari kerusakan arsip yang diakibatkan dari faktor eksternal seperti rayap, jamur dan lain-lain.

3) Tidak adanya kartu kendali peminjaman arsip, sehingga potensi kehilangan arsip atau selipnya arsip sangat besar.

4) Tidak dilakukanya penyusutan arsip, sehingga terjadi penumpukan arsip digudang. 


\section{BAB V KESIMPULAN}

\section{A. Kesimpulan}

Berdasarkan pembahasan yang penulis lakukan pada bab sebelumnya, dapat penulis simpulkan sebagai berikut:

1. Pengolahan arsip dinamis dan statis dilakukan berdasarkan standar deskripsi arsip. Setelah pendeskripsian maka akan ditentukan mana arsip yang harus disimpan dan mana yang dimusnahkan, hal ini berdasarkan pada Jadwal Retensi Arsip (JRA). Setelah proses pengarsipan selesai dilakukan lalu arsip-arsip yang sudah dipisahkan untuk di simpan lalu dilakukan penyatuan arsip-arsip yang sama dan kemudian barulah disimpan. Sedangkan tempat penyimpanan arsip statis, diletakan di sebuah lemari yang yang terbuat dari kayu dan ada yang terbuat dari kaca. Untuk pengkodean yang dilakukan pada arsip dengan memberikan keterangan di map ordner dibagian samping, sehingga arsiparsip itu tertata sesuai dengan kelompoknya.

2. Kelebihan dan kekurangan Pengelolaan Arsip Dinamis dan Statis Di MTs N 2 Pringsewu, adapun kelebihannya adalah Pengelolaan arsip dinamis dan statis di MTs N 2 Pringsewu mempunyai kelebihan diantaranya: pengelolaan arsip dinamis dan statis sudah sesuai dengan undang-undang kearsipan, Tempat penyimpanan arsip menggunkan azaz desentralisasi dan diletakan di samping meja kerja pegawai yang bertanggungjawab dengan kearasipan masing-masing. Sistem penyimpanan arsip dengan menggunkan sistem kronologi, sehingga memudahkan dalam pencarian arsip dari tahun ke tahun. Adanya sistem pendeskripsia arsip, sehingga arsip dapat terseusun sesuai dengan golongan arsip. Sedangkan kekuranganya adalah Pengelolaan arsip yang telah dilakukan oleh MTs N 2 Pringsewu, memiliki kekurangan sebagai berikut: tidak ada ruangan khusus penyimpanan arsip, Masih ada sebagian tempat penyimpanan arsip yang terbuat dari kayu, Tidak adanya kartu kendali peminjaman arsip, Tidak dilakukanya penyusutan arsip, sehingga terjadi penumpukan arsip digudang.

\section{DAFTAR PUSTAKA}

Arikunto, Suharsimi, (2014), $\underline{\text { Prosedur }}$ Penelitian, Suatu Pendekatan praktik, PT. RINEKA CIPTA, Jakarta.

Barthos, Basir, (2016) Manajemen Kearsipan untuk Lembaga Negara, Swasta dan Perguruan Tinggi, Bumi Aksara, Jakarta.

Moleong, Lexy. j, (2016) Metodologi Penelitian Kualitatif, remaja Rosdakarya, Bandung

Muhidin, Sambas Ali dan Hendri Winata, (2016), MANAJEMEN KEARSIPAN, Pustaka Setia, Bandung.

Mulyadi, (2016), Pengelolaan Arsip Berbasis Otomatis, Raja Grafindo Persada, Jakarta.

Sugiarto, Teguh Wahyono, (2015) Menejemen Kearsipan Modern, Gawa media, Yogyakarta.

Sugiyono, (2016), Metode Penelitian Kuantitatif, Kualitatif dan R\&D, Alfabeta, Bandung.

Sulistyo, Basuki, (2015) Manajemen Arsip dinamis (Pengantar memahami dan mengelola informasi dan dokumen), Gramedia Pustaka Utama, Jakarta.

Syahruramadhan, (2017) MANAJEMEN ARSIP DINAMIS DAN STATIS DI

\begin{tabular}{lllr}
\hline KANTOR & \multicolumn{1}{r}{ ARSIP } & DAN \\
\hline PERPUSTAKAAN & KOTA & BIMA \\
\hline (NTB), & Sekripsi, & UIN & Allaudin \\
Makasar. & & & \\
\end{tabular}

Undang-undang Nomor 43 Tahun 2009 dalam Bab I Ketentuan Umum Pasal 1 